\title{
Proteins secreted by the sheep conceptus suppress induction of uterine prostaglandin $F-2 \alpha$ release by oestradiol and oxytocin*
}

\author{
K. B. Fincher $\dagger$, F. W. Bazer $\dagger$, P. J. Hansen, W. W. Thatcher $\ddagger$ and \\ R. M. Roberts $\S$ \\ Departments of $\nmid$ Animal Science, $\ddagger$ Dairy Science and $\S$ Biochemistry and Molecular Biology, \\ University of Florida, Gainesville, Florida 32611, U.S.A.
}

\begin{abstract}
Summary. In Exp. I, $0.5 \mathrm{mg}$ oestradiol or vehicle $(0.5 \mathrm{ml}$ absolute ethanol $+0.5 \mathrm{ml}$ $0.9 \% \mathrm{NaCl}$ ) was injected i.v. at 08:00 h on Day 14 (onset of oestrus = Day 0). Blood samples were obtained via a jugular catheter at 30 and $1 \mathrm{~min}$ before oestradiol and every $30 \mathrm{~min}$ for $10 \mathrm{~h}$ afterwards. Plasma was obtained and assayed for 15-keto13,14-dihydro-PGF-2 $\alpha$ (PGFM) by radioimmunoassay. Before oestradiol, PGFM basal values were higher $(P<0.01)$ in pregnant $(\mathrm{N}=10)$ than nonpregnant $(\mathrm{N}=6)$ ewes $(193 \pm 30$ vs $67 \pm 8 \mathrm{pg} / \mathrm{ml})$. However, at $4-10 \mathrm{~h}$ after oestradiol, pregnant ewes $(\mathrm{N}=5)$ had less variable $(P<0.01)$ PGFM values than did nonpregnant ewes $(\mathrm{N}=5)$. In Exp II, conceptus secretory proteins (CSP) were obtained by pooling medium from cultures of Day-16 sheep conceptuses $(\mathrm{N}=40)$. Ewes received $750 \mu \mathrm{g}$ CSP $+750 \mu$ g plasma protein $(\mathrm{N}=6)$ or $1500 \mu \mathrm{g}$ plasma protein $(\mathrm{N}=6)$ per uterine horn at $08: 00 \mathrm{~h}$ and $18: 00 \mathrm{~h}$ on Days $12-14$. All ewes received $0.5 \mathrm{mg}$ oestradiol at 08:00 h on Day 14 and blood samples were collected as in Exp. I and assayed for PGFM. On Day 15, 3 ewes in each group received $10 \mathrm{i}$.u. oxytocin and 3 received saline i.v. at $08: 00 \mathrm{~h}$ and blood samples were taken continuously from $10 \mathrm{~min}$ before to $60 \mathrm{~min}$ after treatment. Mean PGFM response to oestradiol was suppressed $(P=0.05)$ in CSP- vs plasma protein-treated ewes $(371 \pm 129$ vs $1188 \pm 139 \mathrm{pg} / \mathrm{ml})$. Oxytocin induced a greater $(P<0.01)$ PGFM peak response in plasma protein-treated $(3972 \pm 02199 \mathrm{pg} / \mathrm{ml})$ than CSP-treated $(1669 \pm 287 \mathrm{pg} / \mathrm{ml})$ ewes. Uterine production of PGF in response to oestradiol was suppressed in pregnant and CSP-treated ewes and oxytocin-induced PGF production was also suppressed in CSP-treated ewes. These results are consistent with the theory that CSP act to prevent luteolysis by altering either the amount of PGF released by the uterus or the pattern of PGF release.
\end{abstract}

\section{Introduction}

Oestradiol (Barcikowski, Carlson, Wilson \& McCracken, 1974) and oxytocin (Roberts, Barcikowski, Wilson, Skarnes \& McCracken, 1975) induce premature luteolysis in nonpregnant ewes. However, doses of oestradiol which cause luteolysis in nonpregnant ewes are only partly effective in pregnant ewes (Kittock \& Britt, 1977). McCracken, Schramm \& Okulicz (1984) developed the following general hypothesis to explain events leading to luteolysis in ewes. They proposed that oestradiol induces synthesis of oxytocin receptors which are inserted into the membrane of endometrial cells and that oxytocin binding activates, via activation of adenylate cyclase and cAMP, the arachidonic acid cascade and prostaglandin (PG) F- $2 \alpha$ production. The PGF- $2 \alpha$ is

*Reprint requests to Dr F. W. Bazer. 
the uterine luteolytic hormone in sheep. McCracken et al. (1984) and Zarco, Stabenfeldt, Kindahl, Bradford \& Basu (1984) reported that pulsatile release of PGF-2 $\alpha$ at a frequency of 5.6 episodes per day between Days 15 and 17 of the cycle leads to luteolysis, whereas in nonpregnant ewes, only 1 or 2 PGF episodes per day are detected.

The mechanism whereby the conceptus inhibits the luteolytic effect of PGF in ewes is not understood. However, available evidence suggests that a protein of conceptus origin is involved (Martal, Lacroix, Loudes, Saunier \& Wintenberger-Torres, 1979; Godkin, Bazer, Thatcher \& Roberts, 1984). When proteins secreted by the sheep conceptus (Godkin et al., 1984) or conceptus homogenates (Moor \& Rowson, 1966; Martal et al., 1979) are injected into the uterine lumen of nonpregnant ewes between Days 12 and 18 of the cycle, the interoestrous interval is significantly increased in most ewes. This suggests that conceptus secretory proteins play an essential role in preventing luteolysis and allowing for establishment of pregnancy in ewes.

This study was to: (1) determine the effect of oestradiol-17 $\beta$ on uterine production of PGF, measured indirectly as 15-keto-13,14-dihydro-PGF-2 $\alpha$ (PGFM) in peripheral plasma of nonpregnant and pregnant ewes, and (2) determine whether ovine conceptus secretory proteins alter uterine production of PGF in response to exogenous oestradiol-17 $\beta$ and oxytocin.

\section{Materials and Methods}

Animals. Sexually mature 'Florida Native' ewes were checked daily (07:30-08:00 h) for oestrus using vasectomized rams, and day of onset of oestrus was designated Day 0 . Length of oestrous cycles for the ewes ranged from 16 to 19 days. Ewes assigned to pregnant groups in Exp. I were mated to fertile rams at detection of oestrus and at 12-h intervals thereafter until they failed to exhibit oestrus. Ewes to remain nonpregnant were mated to vasectomized rams. Ewes were fed $0.5 \mathrm{~kg}$ concentrate per day and water and hay ad libitum. The experiments were conducted between 15 August and 1 January of two consecutive breeding seasons (1982 and 1983).

Surgical procedures and catheter placement. Anaesthesia was induced and maintained with methoxyflurane (Metofane: Pitman-Moore, Inc, Washington Crossing, NJ, U.S.A.) administered by a closed-circuit gas anaesthetic machine. In Exp. I, all ewes were fitted with a jugular catheter. The polyvinyl catheter (V6, Bolab, Lake Havasu City, AZ, U.S.A., i.d. $0.86 \mathrm{~mm}$, o.d. $1.52 \mathrm{~mm}$ ) was inserted into the jugular vein and a $36 \mathrm{~cm}$ exteriorized portion was secured to the shaved neck with adhesive tape. The catheters were flushed and filled, when not in use, with heparinized saline (200 i.u./ml 0.155 $\mathrm{M}-\mathrm{NaCl}$ ).

In Exp. II also, ewes were fitted with jugular catheters as described for Exp. I. In addition, catheters were introduced into the lumen of each uterine horn, about $2 \mathrm{~cm}$ below the uterotubal junction, via an incision in the oviduct and secured as described by Godkin et al. (1984).

In Exps I and II ewes were confined to mobile crates during the experimental period to prevent damage to catheters.

Conceptus secretory protein and plasma proteins. Conceptuses $(\mathrm{N}=40)$ were recovered and incubated for $30 \mathrm{~h}$ in $15 \mathrm{ml}$ Minimal Essential Medium at $37^{\circ} \mathrm{C}$ as described by Godkin et al. (1984). The medium from cultures was concentrated and dialysed extensively (1000 $M_{\mathrm{r}}$ cutoffdialysis tubing) against Dulbecco's phosphate-buffered saline (PBS, Dulbecco \& Vogt, 1954), pH $7 \cdot 4$ (6 litres changed four times). The preparation of conceptus secretory proteins (CSP) was filter-sterilized and supplemented with penicillin $(200 \mathrm{U} / \mathrm{ml})$, streptomycin $(200 \mu \mathrm{g} / \mathrm{ml})$ and fungizone $(0.5 \mu \mathrm{g} / \mathrm{ml}$ ). The protein concentration was $0.4 \mathrm{mg} / \mathrm{ml}$ (Lowry, Rosebrough, Farr \& Randall, 1951).

Plasma protein from a Day- 16 pregnant ewe was diluted to $0.4 \mathrm{mg} / \mathrm{ml}$ in MEM and prepared as described for CSP. Samples were stored at $-20^{\circ} \mathrm{C}$ until used in Exp. II. 
Hormone preparations. In Exps I and II, $100 \mathrm{mg}$ oestradiol-17 $\beta$ (Sigma Chemical Co., St Louis, MO, U.S.A.) were dissolved in $100 \mathrm{ml}$ absolute ethanol and stored at $4{ }^{\circ} \mathrm{C}$. At the time of injection $500 \mu \mathrm{g}$ oestradiol $-17 \beta$ in $0.5 \mathrm{ml}$ ethanol were mixed with $0.5 \mathrm{ml} 0.9 \%(\mathrm{w} / \mathrm{v}) \mathrm{NaCl}$ (vehicle) for injection via jugular catheter.

Oxytocin (Sigma) was dissolved in $0.9 \%(\mathrm{w} / \mathrm{v}) \mathrm{NaCl}$ solution at $10 \mathrm{i} . \mathrm{u} . / \mathrm{ml}$ and $1 \mathrm{ml}$ was injected via the jugular catheter on Day 15 in Exp. II.

PGFM radioimmunoassay. Concentrations of PGFM in plasma were measured using a double-antibody RIA with a sensitivity of $50 \mathrm{pg} / \mathrm{ml}$. Repetitive measurements of reference plasma $(800 \mathrm{pg} / \mathrm{ml})$ in duplicate among 10 assays were used to determine intrassay (Exp. $I=9 \cdot 4 \%$; Exp. II $=8.0 \%)$ and interassay (Exp. I $=15 \cdot 2 \%$; Exp. $I I=7 \cdot 1 \%)$ coefficients of variation. Crossreactivity of the antibody to PGFM with PGF-2 $\alpha$, PGE-2 and 6-keto PGF-2 $\alpha$ was less than $1 \%$ (Guilbault, Thatcher, Drost \& Hopkins, 1984).

The assay was validated for PGFM in sheep plasma by adding $250,500,1000$ or 2000 pg PGFM to PGFM-free plasma from wethers and quantifying recoverable mass. Recovery of added $(x)$ versus measured $(y)$ PGFM concentrations was described by a linear regression $(y=42 \cdot 0+1 \cdot 03 x$; $\left.R^{2}=0.96\right)$.

In this study, concentrations of PGFM are assumed to reflect primarily hormone-induced changes in uterine production of PGF. Louis, Parry, Robinson, Thorburn \& Challis (1977) first reported a correlation $(r=0.6, P<0.01)$ between PGF concentrations in right and left utero-ovarian vein plasma and PGFM in jugular vein plasma of ewes. Since then several studies have established that temporal changes in PGF and PGFM are comparable and correlate well with physiological events resulting in increased rates of PGF production by the uterus, e.g. during luteolysis and parturition (see Bazer, Sharp, Thatcher \& Roberts, 1981).

Experiment I. Ewes were assigned randomly to one of the following groups: (1) 5 ewes were mated to fertile rams and injected i.v. with $0.5 \mathrm{mg}$ oestradiol on Day 14 of pregnancy; (2) 5 ewes were mated to fertile rams and injected with vehicle only on Day 14 of pregnancy; and (3) 6 ewes were mated with vasectomized rams and injected i.v. with $0.5 \mathrm{mg}$ oestradiol on Day 14 of the oestrous cycle. All ewes were fitted with jugular catheters on Day 12. On Day 14 two pretreatment blood samples were obtained at 07:30 h and 08:00 h. Treatment was given immediately after the 08:00 h sample and post-treatment samples were taken at 30-min intervals until 18:00 h. All samples were kept on ice until centrifuged at $100 \mathrm{~g}$ for $20 \mathrm{~min}$ at $4^{\circ} \mathrm{C}$. Plasma was stored at $-20^{\circ} \mathrm{C}$ until assayed for PGFM to determine effects of pregnancy on uterine production of PGF in response to the oestradiol. On Day 15 ewes were anaesthetized, the reproductive organs were exposed by mid-ventral laparotomy, and the presence of conceptuses in pregnant ewes was confirmed. All ewes mated to fertile rams had morphologically normal conceptuses.

Experiment II. Ewes mated with vasectomized rams and fitted with uterine and jugular catheters on Day 10 of the oestrous cycle were assigned randomly to receive bilateral intrauterine injections of: (1) $0.75 \mathrm{mg}$ CSP plus $0.75 \mathrm{mg}$ plasma proteins per injection $(\mathrm{N}=6)$ or (2) $1.50 \mathrm{mg}$ plasma protein only per injection $(\mathrm{N}=6)$. All 12 ewes received intrauterine injections at $08: 00 \mathrm{~h}$ and 18:00 h on Days 12, 13 and 14. On Day 14 all ewes were injected with $0.5 \mathrm{mg}$ oestradiol via the jugular catheter at 08:02 $\mathrm{h}$ and pretreatment as well as post-treatment blood samples were collected for assay of plasma PGFM concentrations as described for Exp I. On Day 15 one-half of the ewes in each treatment group were injected with $10 \mathrm{i}$.u. oxytocin via the jugular catheter. The other ewes received an i.v. injection of $1 \mathrm{ml} 0.9 \%(\mathrm{w} / \mathrm{v}) \mathrm{NaCl}$ via the jugular catheter. Blood samples were withdrawn continuously, $1 \mathrm{ml} / \mathrm{min}$, using an automated withdrawal pump and syringes were changed every $10 \mathrm{~min}$ before oxytocin or saline injection until $60 \mathrm{~min}$ after injection. Samples were centrifuged at $1000 \mathrm{~g}$ for $15 \mathrm{~min}$, and plasma was removed and stored at $-20^{\circ} \mathrm{C}$ until assayed for PGFM. All ewes were observed for oestrus daily in the presence of vasectomized rams and laparotomized the day after oestrus was detected or on Day 25. At surgery, catheter placement in 
the uterine lumen was confirmed, as was presence of the corpus luteum or corpus albicans marked with India ink at the previous surgery.

Statistical analysis. Data were analysed by least squares analysis of variance and polynomial response curves generated to describe temporal changes in PGFM (Barr, Goodnight, Sall, Blair \& Chilko, 1979). The statistical model allowed determination of effects of treatment, time after treatment, treatment by time interaction and ewe within treatment on PGFM concentrations in plasma.

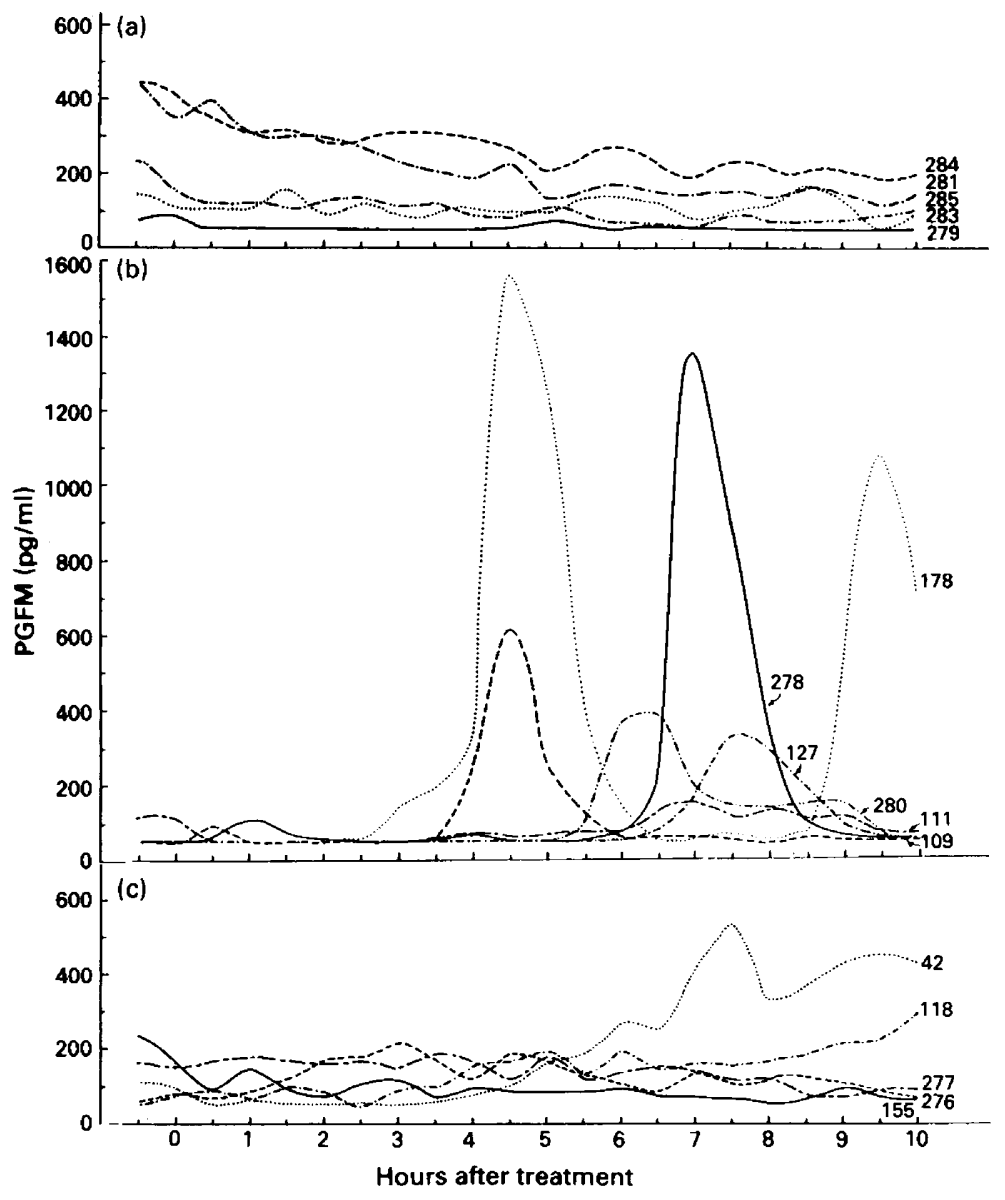

Fig. 1. Concentrations of PGFM in plasma from (a) 5 pregnant ewes treated with ethanolsaline vehicle; (b) 6 nonpregnant ewes treated with $0.5 \mathrm{mg}$ oestradiol- $17 \beta$ at $0 \mathrm{~h}$; and (c) 5 pregnant ewes treated with $0.5 \mathrm{mg}$ oestradiol- $17 \beta$ at $0 \mathrm{~h}$. Individual ewe numbers identify the response curve for each ewe.

Time was considered a continuous independent variable. Tests for homogeneity of regression were used to detect differences in PGFM response curves amongst treatment groups (Snedecor \& Cochran, 1969). Equality of variances were tested by $\chi^{2}$ using the ratio of larger to smaller estimates of variance (Steel \& Torrie, 1960). 


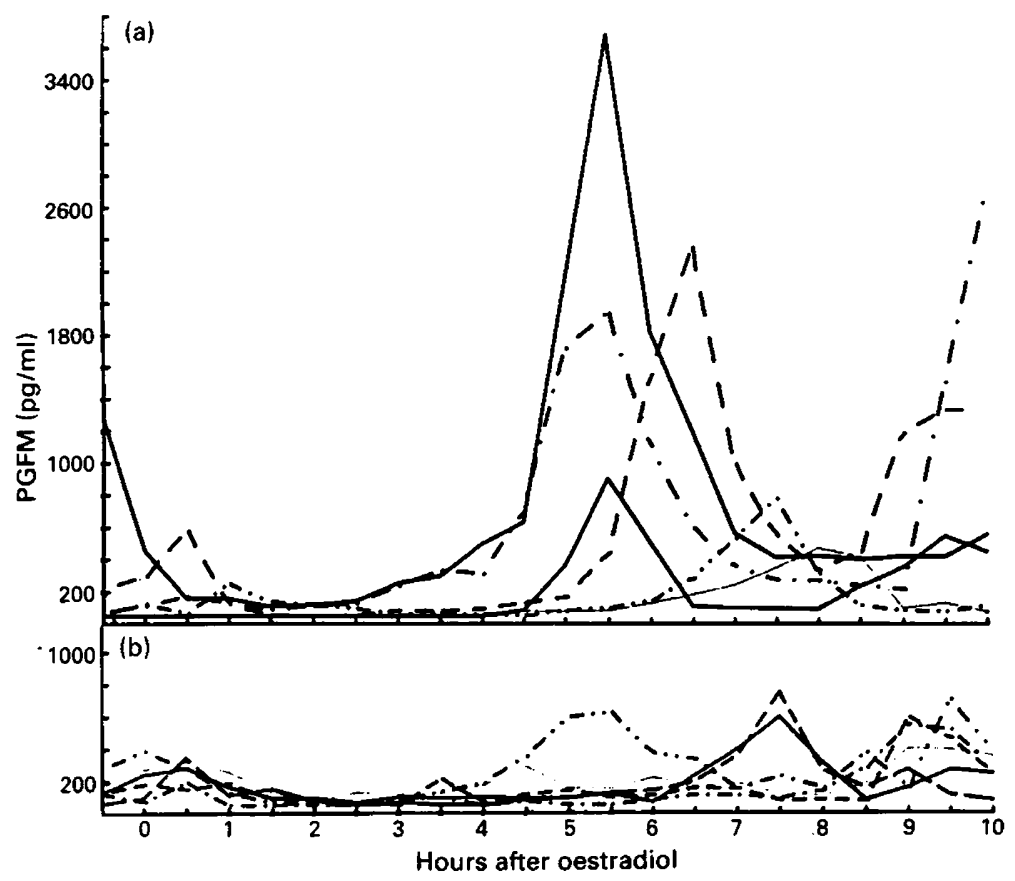

Fig. 2. Concentrations of PGFM in plasma in response to $0.5 \mathrm{mg}$ oestradiol-17 $\beta$ for (a) 5 ewes receiving intrauterine injections of plasma protein (PP) and (b) 5 ewes receiving intrauterine injections of conceptus secretory proteins on Days 12-14 of the oestrous cycle.

\section{Results}

\section{Experiment I}

Before treatment with oestradiol or vehicle, mean ( \pm s.e.m.) concentrations of PGFM were greater for pregnant $(\mathrm{N}=10 ; 193 \pm 30 \mathrm{pg} / \mathrm{ml})$ than nonpregnant $(\mathrm{N}=5 ; 67 \pm 8 \mathrm{pg} / \mathrm{ml})$ ewes. For pregnant ewes receiving vehicle only (Fig. 1a) concentrations of PGFM in plasma remained relatively constant during the 10 -h sampling period. However, nonpregnant ewes treated with oestradiol responded with highly variable episodes of elevated PGFM 4-8 h after oestradiol injection $(148-1350 \mathrm{pg} / \mathrm{ml})$ and in one ewe a second episode of elevated PGFM was detected at $9.5 \mathrm{~h}$ (Fig. 1b). Pregnant ewes treated with oestradiol did not respond with episodes of elevated PGFM, and only one ewe had PGFM concentrations that exceeded $200 \mathrm{pg} / \mathrm{ml}$ (Fig. 1c). The other ewes in that group maintained relatively constant PGFM concentrations $(141 \pm 80 \mathrm{pg} / \mathrm{ml})$.

There was heterogeneity of regression $(P<0.01)$ amongst PGFM responses of the three treatment groups. Injection of vehicle to pregnant ewes failed to induce a PGFM response compared to the two oestradiol-treated groups $(P<0.01)$. Injection of oestradiol induced a greater increase in PGFM in nonpregnant ewes; but, statistically significant differences between treatment groups were not detected because of the heterogeneity of variances. Nevertheless, pregnant ewes treated with oestradiol had less variable $(P<0.01)$ concentrations of PGFM. Data were transformed to natural logarithms and analysed. Again, heterogeneity of regression between the three treatment groups $(P<0.01)$ was detected. Tests for homogeneity of regression indicated, however, that PGFM response to oestradiol by pregnant ewes differed from that for nonpregnant ewes $(P<0.05)$. 


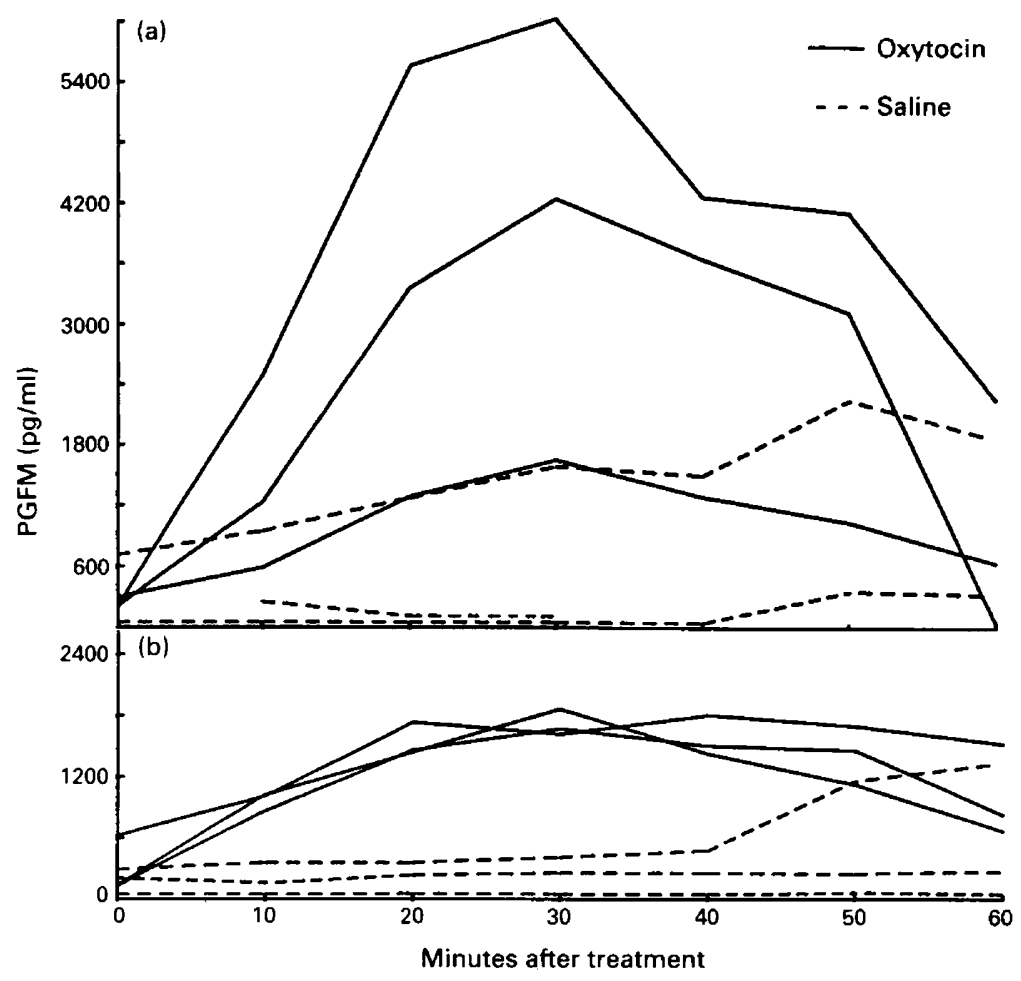

Fig. 3. Concentrations of PGFM in plasma in response to i.m. injections of 10 i.u. oxytocin or saline for 3 ewes per treatment receiving injections of (a) plasma proteins (PP) or (b) conceptus secretory proteins (CSP).

\section{Experiment $I I$}

Concentrations of PGFM in plasma were lower $(P<0 \cdot 10)$ for CSP-treated ewes and there was a sampling time by treatment interaction $(P<0.01)$ indicating that changes in PGFM induced by oestradiol were different in CSP- and plasma protein-treated ewes (Fig. 2). The ewes treated with plasma protein responded to oestradiol with episodes of elevated PGFM 4-8 h later, as for nonpregnant ewes in Exp. I, and the magnitude of PGFM response was again highly variable (mean \pm s.e.m., $1747 \pm 1339 \mathrm{pg} / \mathrm{ml}$; range $=468-3764 \mathrm{pg} / \mathrm{ml}$ ). The beginning of a second increase in PGFM was detected in 3 of 6 ewes when sampling was discontinued at $10 \mathrm{~h}$ after treatment. None of 6 CSP-treated ewes had PGFM concentrations that exceeded $750 \mathrm{pg} / \mathrm{ml}$ (mean \pm s.e.m., $595 \pm 123 \mathrm{pg} / \mathrm{ml}$; range $397-747 \mathrm{pg} / \mathrm{ml}$ ). Heterogeneity of regression $(P<0.01)$ in concentrations of PGFM between CSP- and plasma protein-treated ewes indicated that CSP altered the oestradiol-induced PGFM response.

Approximately $24 \mathrm{~h}$ after oestradiol injection (Day 15), CSP and plasma protein-treated ewes received injections of $10 \mathrm{i}$.u. oxytocin or $1 \mathrm{ml}$ saline. A PGFM response was induced by injection of oxytocin $(P<0 \cdot 10)$ and time of sampling by injection interaction $(P<0.01)$ was also detected (Fig. 3). This interaction indicated that the response to saline was less than that for oxytocin. Peak PGFM response to oxytocin occurred at $30 \mathrm{~min}$ in each group. In the plasma protein-oxytocin group, peak PGFM (mean \pm s.e.m.) was $3972 \pm 2199 \mathrm{pg} / \mathrm{ml}$ and peak concentrations exceeded $3674 \mathrm{pg} / \mathrm{ml}$ in 2 of 3 ewes. The CSP-treated ewes had a less variable PGFM response $(1669 \pm 287 \mathrm{pg} / \mathrm{ml})$ and values did not exceed $2000 \mathrm{pg} / \mathrm{ml}$. A protein (CSP vs plasma protein) by 
injection (oxytocin $v s$ saline) interaction $(P<0.01)$ indicated that the PGFM response to oxytocin was greater in ewes treated with plasma protein than in those receiving CSP. In addition, interoestrous interval (mean \pm s.d.) was greater $(P<0 \cdot 10)$ for CSP-treated $(22 \pm 4$ days) than for plasma protein-treated (18 \pm 2 days) ewes.

\section{Discussion}

The luteolytic effect of oestradiol (Barcikowski et al., 1974) and oxytocin (see Fairclough, Moore, Peterson \& Watkins, 1984) late in the oestrous cycle of sheep has been demonstrated. However, oestradiol-induced release of uterine PGF is attenuated in the presence of the conceptus in the cow (Thatcher et al., 1984) and ewe (Kittock \& Britt, 1977). In the ewe, the conceptus also attenuates oxytocin-induced production of PGF by the uterus (Fairclough et al., 1984). Data from Exp. I indicated that pregnant ewes responded to oestradiol with reduced PGF release from the uterus compared to nonpregnant ewes. Five of 6 nonpregnant ewes responded to oestradiol with major episodes of PGF release 4-8 h after oestradiol. However, all pregnant ewes treated with oestradiol maintained relatively constant PGFM levels and no major episodes were detected. Basal PGFM concentrations, however, were higher in pregnant ewes, probably due to PGF production by the conceptus (Marcus, 1981).

Data from Exp. I established a model of differential PGF release from the uterus by pregnant and nonpregnant ewes which allowed effects of CSP to be tested. The CSP were injected into nonpregnant uteri during the time when the conceptus 'signals' its presence to the maternal system (Moor \& Rowson, 1966). The PGFM response to oestradiol was suppressed in CSP-treated ewes, as in pregnancy (Exp. I). In addition, the PGFM response to oxytocin was suppressed in CSPtreated ewes, and mean interoestrous interval was extended despite the two potent hormonal challenges known to induce luteolysis in nonpregnant ewes. The ovine conceptus apparently produces one or more proteins capable of suppressing PGF release by the endometrium, but site and mechanism of action of CSP have not been elucidated.

Ovine luteal tissue contains high concentrations of oxytocin (Wathes \& Swann, 1982; Flint \& Sheldrick, 1982a) and oxytocin receptors have been identified in ovine endometrium (Roberts, McCracken, Gavagan \& Soloff, 1976). Oxytocin is thought to be involved in stimulating normal luteal regression since: (1) active immunization against oxytocin delays luteolysis (Sheldrick \& Flint, 1984; Schams, Prokopp \& Schmidt-Adamopoulou, 1982); (2) peaks of oxytocin-associated neurophysin and PGF occur coincidentally late in the cycle (Fairclough et al., 1980); and (3) exogenous administration of oxytocin induces luteolysis (Mitchell, Flint \& Turnbull, 1975; Roberts et al., 1976). Luteal secretion of oxytocin is stimulated by the PGF analogue, cloprostenol (Flint \& Sheldrick, 1982b); therefore, CL regression may result from a systemic positive feedback loop involving initial secretion of PGF by the uterus and subsequent release of oxytocin from the CL which would reinforce PGF production by the uterus. Interruption in this mechanism may alter episodic release of PGF and allow extended corpus luteum function, while basal prostaglandin production may actually increase. Since basal PGFM concentrations are elevated during early pregnancy according to present results and those of others (Wilson, Cenedella, Butcher \& Inskeep, 1972; Ellinwood, Nett \& Niswender, 1979), interference with uterine PGF secretion during gestation may not occur at the oxytocin receptor level. Alternatively, the production of PGF and PGE by the sheep conceptus may account for elevated basal values of PGFM in pregnant ewes.

The conceptus-produced proteins may alter enzymic conversion of intermediates in prostaglandin biosynthesis, which may explain the increase in the ratio of PGE-2:PGF-2 $\alpha$ reported for pregnant ewes between Days 13 and 15 (Silvia, Ottobre \& Inskeep, 1984). Prostaglandins E-2 and F- $2 \alpha$ are derived from a common endoperoxide intermediate (Hamberg \& Samuelsson, 1973); and driving synthesis toward one product therefore reduces levels of the other. The diversity of biological activities of the two prostaglandins (Horton, 1972; Hinman, 1972) suggests that physiological 
processes such as luteolysis could be efficiently controlled by stimulating enzymic pathways favouring high PGE-2:PGF-2 $\alpha$ ratios.

The CSP may act on uterine endometrium to inhibit oestradiol and oxytocin-induced PGF production. The CSP probably do not affect PGF- $2 \alpha$ production at the level of the oestradiol receptor, since many other oestradiol effects are required and have been observed throughout gestation (Catchpole, 1977). However, the luteolytic effect of oestradiol is inhibited by infusion of CSP which is consistent with earlier reports for pregnant ewes (Kittock \& Britt, 1977) and cows (Thatcher et al., 1984).

The conceptus proteins may also alter binding of oxytocin to its receptor. Suppression of oxytocin-induced PGFM response by CSP in Exp. II could be due to decreased oxytocin receptor numbers, as occurs in pregnant sheep (McCracken et al., 1984), or to competitive binding of conceptus protein to the receptor. However, basal PGFM concentrations were elevated in Exp. I, perhaps due to conceptus PGF production, as reported previously (Marcus, 1981). Therefore, it appears that the difference in response to oxytocin between CSP- and plasma protein-treated ewes is regulated at a point beyond the receptor level, perhaps through differences in activity of enzymes affecting synthesis and/or metabolism of prostaglandins.

Zarco et al. (1984) reported that the mean number of PGFM pulses per $25 \mathrm{~h}$ in nonpregnant ewes was 5.5 compared to only 1.3 in pregnant ewes, although PGE-2 increases dramatically between Days 13 and 15 of pregnancy (Silvia et al., 1984). It is possible that PGF-2 $\alpha$ is readily converted to PGE-2 in the presence of oxidized cofactors (Lee \& Levine, 1974) which would reduce the number of PGF peaks in early pregnancy. Concentrations of PGE-2 in the circulation of CSP-and plasma protein-treated ewes receiving oestradiol and oxytocin have not been determined.

This research was supported by NIH Grant HD10436. This is Journal Series Paper No. 6540 of the University of Florida Agricultural Station.

\section{References}

Barcikowski, B., Carlson, J.C., Wilson, L. \& McCracken, J.A. (1974) The effect of endogenous and exogenous estradiol-17 $\beta$ on the release of prostaglandin $F_{2 \alpha}$ from the ovine uterus. Endocrinology 95, 1340-1349.

Barr, A.J., Goodnight, J.H., Sall, J.P., Blair, W.H. \& Chilko, B.M. (1979) SAS User's Guide. SAS Institute Inc., Raleigh, NC, U.S.A.

Bazer, F.W., Sharp, D.C., Thatcher, W.W. \& Roberts, R.M. (1981) Comparative approach to mechanisms in the maintenance of early pregnancy. In Reproductive Processes and Contraception, pp. 581-618. Ed. K.W. McKerns. Plenum Press, New York.

Catchpole, H.R. (1977) Hormonal mechanisms in pregnancy and parturition. In Reproduction in Domestic Animals, pp. 341-368. Eds. H. H. Cole \& P. T. Cupps. Academic Press, New York.

Dulbecco, R. \& Vogt, M. (1954) Plaque formation and isolation of pure lines with poliomyelitis viruses. $J$. exp. Med. 99, 167-199.

Ellinwood, W.B., Nett, T.M. \& Niswender, G.D. (1979) Maintenance of the corpus luteum of early pregnancy in the ewe. II. Prostaglandin secretion by the endometrium in vitro and in vivo. Biol. Reprod. 21, 845-856.

Fairclough, N.J., Moore, L.G., McGowan, L.T., Peterson, A.J., Smith, J.F., Tervit, H.R. \& Watkins,
W.B. (1980) Temporal relationship between plasma concentrations of 13,14-dihydro-15-keto prostaglandin $\mathrm{F}$ and neurophysin $\mathrm{I} / \mathrm{II}$ around luteolysis in sheep. Prostaglandins 20, 199-208.

Fairclough, R.J., Moore, L.G., Peterson, A.J. \& Watkins, W.B. (1984) Effect of oxytocin on plasma concentrations of 13,14-hydro-15 keto-prostaglandin $F$ and the oxytocin associated neurophysin during the estrous cycle and early pregnancy in the ewe. Biol. Reprod. 31, 36-43.

Flint, A.P.F. \& Sheldrick, E.L. (1982a) Ovarian secretion of oxytocin in the sheep. J. Physiol., Lond. 330, $61 P-62 P$.

Flint, A.P.F. \& Sheldrick, E.L. (1982b) Ovarian secretion of oxytocin is stimulated by prostaglandin. Nature, Lond. 297, 587-588.

Godkin, J.D., Bazer, F.W., Thatcher, W.W. \& Roberts, R.M. (1984) Proteins released by cultured Day 15-16 conceptuses prolong luteal maintenance when introduced into the uterine lumen of cyclic ewes. $J$. Reprod. Fert. 71, 57-64.

Guilbault, L.A., Thatcher, W.W., Drost, M. \& Hopkins, S.M. (1984) Source of F series prostaglandins during the early postpartum period in cattle. Biol. Reprod. 31, 879-887.

Hamberg, M. \& Samuelsson, B. (1973) Detection and 
isolation of an endoperoxide intermediate in prostaglandin biosynthesis. Proc. natn. Acad. Sci., U.S.A. 70, 899-903.

Hinman, J.W. (1972) Prostaglandins. Annu. Rev. Biochem. 41, 161-178.

Horton, E.W. (1972) The prostaglandins. Proc. R. Soc. Lond. 182, 411-426.

Kittock, R.J. \& Britt, J.H. (1977) Corpus luteum function in ewes given estradiol during the estrous cycle or early pregnancy. J. Anim. Sci. 45, 336-341.

Lee, S. \& Levine, L. (1974) Prostaglandin metabolism. J. biol. Chem. 249, 1369-1375.

Louis, T.H., Parry, D.M., Robinson, J.S., Thorburn, C.D. \& Challis, J.R.G. (1977) Effects of exogenous progesterone and oestradiol on prostaglandin $B$ and 13,14-dihydro-15-oxo prostaglandin $F_{2 a}$ concentrations in uteri and plasma of ovariectomized ewes. J. Endocr. 73, 247-439.

Lowry, O.H., Rosebrough, N.J., Farr, A.L. \& Randall, R.J. (1951) Protein measurement with the Folin phenol reagent. J. biol. Chem. 193, 265-275.

Marcus, G. (1981) Prostaglandin formation by the sheep embryo and endometrium as an indication of maternal recognition of pregnancy. Biol. Reprod. 25, $56-64$.

Martal, J., Lacroix, M.C., Loudes, C., Saunier, M. \& Wintenberger-Torres, S. (1979) Trophoblastin, an anti-luteolytic protein present in early pregnancy in sheep. J. Reprod. Fert. 56, 63-73.

McCracken, J.A., Schramm, W. \& Okulicz, W.C. (1984) Hormone receptor control of pulsatile secretion of $\mathrm{PGF}_{2 a}$ from the ovine uterus during luteolysis and its abrogation in early pregnancy. Anim. Reprod. Sci. 7,31-55.

Moor, R.M. \& Rowson, L.E.A. (1966) Local uterine mechanisms affecting luteal function in the sheep. $J$. Reprod. Fert. 11, 307-310.

Mitchell, M.D., Flint, A.P.F. \& Turnbull, A.C. (1975) Stimulation by oxytocin of prostaglandin $F$ levels in uterine venous effluent in pregnant and puerperal sheep. Prostaglandins 9, 47-56.

Roberts, J.S., Barcikowski, B., Wilson, L., Skarnes, C. \& McCracken, J.A. (1975) Hormonal and related factors affecting the release of prostaglandin $F_{2 a}$ from the uterus. J. Steroid Biochem. 6, 1091-1097.
Roberts, J.S., McCracken, J.A., Gavagan, J.E. \& Soloff, M.S. (1976) Oxytocin-stimulated release of prostaglandin $\mathrm{F}_{2 a}$ from ovine endometrium in vitro: correlation with estrous cycle and oxytocin-receptor binding. Endocrinology 99, 1107-1114.

Schams, D., Prokopp, A. \& Schmidt-Adamopoulou, B. (1982) The effect of active immunization against oxytocin on ovarian cyclicity in ewes. Acta endocr., Copenh., Suppl. 246, 7, Abstr. 8.

Sheldrick, E.L. \& Flint, A.P.F. (1984) Ovarian oxytocin and luteal function in the early pregnant sheep. Anim. Reprod. Sci. 7, 101-113.

Silvia, W.J., Ottobre, J.S. \& Inskeep, E.K. (1984) Concentrations of prostaglandins $E_{2}, F_{2 a}$ and 6-ketoprostaglandin $\mathrm{F}_{1 \alpha}$ in the utero-ovarian venous plasma of nonpregnant and early pregnant ewes. Biol. Reprod. 30, 936-944.

Snedecor, C.W. \& Cochran, W.C. (1969) Statistical Methods. Iowa State University Press, Ames, IA.

Steel, R.C.D. \& Torrie, J.H. (1960) Principles and Procedures of Statistics. McGraw-Hill, New York, U.S.A.

Thatcher, W.W., Wolfenson, D., Curl, J.S., Rico, L.E., Knickerbocker, J.J., Bazer, F.W. \& Drost, M. (1984) Prostaglandin dynamics associated with development of the bovine conceptus. Anim. Reprod. Sci. 7, 149-176.

Wathes, D.C. \& Swann, R.W. (1982) Is oxytocin an ovarian hormone? Nature, Lond. 297, 225227.

Wilson, L., Jr, Cenedella, R.J., Butcher, R.L. \& Inskeep, E.K. (1972) Levels of prostaglandins in the uterine endometrium during the ovine estrous cycle. J. Anim. Sci. 34, 93-99.

Zarco, L., Stabenfeldt, G.H., Kindahl, H., Bradford, G.E. \& Basu, S. (1984) A detailed study of prostaglandin $\mathrm{F}_{2 a}$ release during luteolysis and establishment of pregnancy in the ewe. Biol. Reprod. 30 (Suppl. 1), 153, Abstr.

Received 19 June 1985 